ENTREPRENEURSHIP AND SUSTAINABILITY ISSUES

ISSN 2345-0282 (online) http://jssidoi.org/jesi/

2020 Volume 7 Number 4 (June)

http://doi.org/10.9770/jesi.2020.7.4(12)

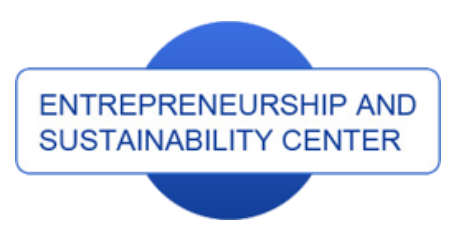

Publisher

http://jssidoi.org/esc/home

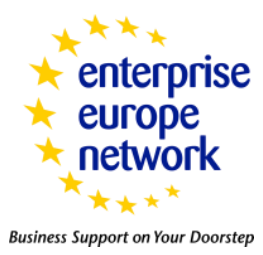

CASPA

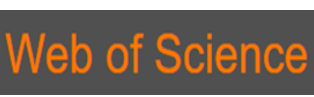

1) Clarivate

Analytics

\title{
MULTIPLE SYSTEM OF INNOVATION-INVESTMENT DECISIONS ADOPTION WITH SYNERGETIC APPROACH USAGE
}

\author{
Svitlana Khalatur ${ }^{1}$, Svitlana Khaminich ${ }^{2}$, Oksana Budko ${ }^{3}$, Olesia Dubovych ${ }^{4}$, \\ Oleksandr Karamushka ${ }^{5}$ \\ 1, 5 Dnipro State Agrarian and Economic University, Serhii Efremov Str., 25, Dnipro, Ukraine \\ ${ }^{2}$ Oles Honchar Dnipro National University, Gagarin Avenue, 72, Dnipro, Ukraine \\ 3 Dniprovsk State Technical University, Dniprobudivs'ka, str. 2, Kamenskoe, Ukraine \\ ${ }^{4}$ Poltava State Agrarian Academy, 1/3 Skovorody str., Poltava, Ukraine \\ E-mails: ${ }^{1}$ skhalatur@gmail.com $;{ }^{2}$ svetlana1704@i.ua ; ${ }^{3}$ alesiy-d@ukr.net; ${ }^{4}$ bisnescon@ukr.net \\ ${ }^{5}$ k80504949768@gmail.com
}

Received 18 November 2019; accepted 20 March 2020; published 30 June 2020

\begin{abstract}
The purpose of the article was to comprehensively study and systematize knowledge about the essence, sources of origin and evaluation of synergistic effect in integration processes of national economy in order to build a conceptual scheme of its receipt in the implementation of integration interaction. The conducted research has shown that, a multi-level system of making innovative investment decisions using a synergistic approach is necessary to identify and build up a positive synergistic effect from the combination and interaction of assets and sources of financing, evaluation of the end results of such interaction, cooperation of labor, integration of industries, production integration. For example, the financing of the banking system of the agrarian sector of the Ukrainian economy was considered. The practical significance of the research is that the scientific developments will enable the formation of an effectively functioning agro-industrial complex in Ukraine with optimal financing based on the use of a multi-level system of making innovative investment decisions using a synergistic approach. Further studies are in the field of studying the system-forming factors and patterns of behavior of economic systems in terms of restoring the synergy potential.
\end{abstract}

Keywords: synergy; synergistic effect; lending, agriculture; innovation; investment

Reference to this paper should be made as follows: Khalatur, S., Khaminich, S., Budko, O., Dubovych, O., Karamushka, O. 2020. Multiple system of innovation-investment decisions adoption with synergetic approach usage. Entrepreneurship and Sustainability Issues, 7(4), 2745-2763. http://doi.org/10.9770/jesi.2020.7.4(12)

JEL Classification: G21, O11, Q14

\section{Introduction}

The main feature of modern economy development trends is its innovative orientation. As a result of scientific and technological progress, the world has received a strong impetus, which stimulates the replacement of technology and scientific developments in material production. As an example, let's consider agriculture as a 


\section{ENTREPRENEURSHIP AND SUSTAINABILITY ISSUES}

ISSN 2345-0282 (online) http://jssidoi.org/jesi/

2020 Volume 7 Number 4 (June)

http://doi.org/10.9770/jesi.2020.7.4(12)

strategically important sector of the country's economy. Among the main factors of economic growth of agricultural production are banking system financing. The necessity and special role of credit, without which the producer cannot exist, are determined by the specifics of its reproduction process. Most agricultural enterprises potential borrowers - are not attractive creditors because of their low creditworthiness. Such creditworthiness is caused by unsatisfactory financial condition, lack of liquidity and high risks of lending to the enterprises of the industry.

Due to the lack of funds needed for the agro-industrial complex development, insignificant participation in the lending of agricultural commodity producers of universal banks, the priority of development of the agrarian sector should be the formation of an effective lending mechanism that can meet the high demand in the agricultural credit market and overcome the tendency of low credit supply from commercial banks and lack of sources of selffinancing for agricultural enterprises. Changes in the economic situation exacerbate the old and cause new problems that need to be solved in a timely search for new ones and improve the traditional credit mechanisms of agriculture.

The main constraints on the credit market development in the agricultural sector today are: long-term decline in bank lending activity, orientation of bank lending activity in non-productive industries, high cost of loans, limitation of long-term credit for 3-5 years, low level of creditworthiness of agricultural holdings due to the high level of operation and moral obsolescence of fixed assets of agricultural enterprises, the limited infrastructure of the credit market.

So, Gai and Kapadia (2019) investigate the solvency and liquidity crises of the financial system. Kanbur (2019) writes that inequality is a matter of the moment. In many rich countries, including the United States, there is a clear upward trend in income inequality. A study by Deloof et al (2019) provides new data on the implications of developing advanced banking systems in the country to fund new businesses. Grishnova, Cherkasov and Brintseva (2019) explored one of the pressing issues of the national economy: how, by what principles, by what system, how workers should be compensated, and how income should be organized in the new economy, in the new job market. Amoro et al (2019) consider two types of entrepreneurship: entrepreneurship based on opportunities linked to innovation; need-based entrepreneurship is starting a business through pressure as a way to compensate for the absence of other sources of employment. Jarkinbayev and Kosherbayeva (2018) argue that in the face of global economic instability, there is a growing need for accurate forecasts of macroeconomic indicators to make informed decisions on the implementation of the socio-economic policies of the state.

Wang \& Lee (2011) argue that investors often need to evaluate investment strategies according to their own subjective preferences based on different criteria. Serrano-Cinca \& Gutiérrez-Nieto (2013) propose a decisionmaking model that assesses various aspects related to investment decisions. Winkler (1997) explores how cohabitants make economic decisions. Pauraa and Arhipovaa (2016) examined dairy production, which is of great importance for the European Union and is one of the important sectors of the agricultural economy. LindholmDahlstrand,et al (2018) note that new knowledge is a major source of economic growth. Xiao, (2015) argue that in recent decades, the economic slowdown of major advanced economies in Europe has driven both academic and political concern for entrepreneurship. Collewaert and Fassin (2013) developed proposals for the impact of perceived unethical behavior on the conflict process between investors, venture capitalists and entrepreneurs. Frishammar et al (2019) identify new innovation audit activities and practices; Hallberg and Brattström (2019) have developed a model that outlines the impact of knowledge that shows the value of innovation, the price of products, the comparative value of innovation, and the corresponding moderators of these effects. Cobeña et al (2017) reveal the concepts of partner heterogeneity, the diversity of alliance portfolios, and the complementarity of network resources to gain a deeper understanding of alliance portfolio configuration and how it affects performance. Calvo-Mora et al (2016) study the impact of process methodology and partner management, as well as the relationship between this variable and key business outcomes. Brix-Asala et al (2016) highlight the 


\section{ENTREPRENEURSHIP AND SUSTAINABILITY ISSUES}

ISSN 2345-0282 (online) http://jssidoi.org/jesi/

2020 Volume 7 Number 4 (June)

http://doi.org/10.9770/jesi.2020.7.4(12)

opportunities and disadvantages of informal valorisation in return logistical activities, both socially and environmentally. Chulkova et al (2017) study the issues of increasing the investment attractiveness of agriculture, where economic security comes first and actually becomes a topic of food security.

It is advisable to investigate the improvement of the credit system of the borrowers of the agricultural sector of the economy through the prism of neutralization or reduction of the effect of the mentioned number of factors. Today, the practice of conducting domestic agrarian business with the attraction of credit for seasonal needs, modernization and construction of new production facilities has been formed. Most representatives of the agricultural sector of the economy use short and long-term loans and in the current conditions, a significant decrease in lending activity of banks lacks them.

Therefore, the domestic banking system plays an important role in the agriculture regarding the continuity of the reproduction process and the development of entrepreneurial activity; the study and justification of the need for a multi-level system of making innovative investment decisions using a synergistic approach has theoretical and practical importance.

\section{Purpose of article}

The research of economic systems' development problems on the basis of synergetic approach substantiated the relevance of the tasks, which are fulfilled in this article:

1. Generalization of the synergistic concept components and identification of the economic systems development features on the basis of the systematic approach and the general theory of systems.

2. Analysis of the current state of the agro-industrial complex financing by banking institutions, submission of proposals for the further effective financing of the agricultural enterprises in the Ukrainian economy based on synergistic effect.

3. Consideration of the innovation-investment process as a source of synergy formation, which creates preconditions for the potential of self-organization and reproduction of the real sector cycles of the economy.

The purpose of the article is to comprehensively study and systematize knowledge about the essence, sources of origin and evaluation of synergistic effect in integration processes to build a conceptual scheme of its receipt during the integration interaction.

\section{Theoretical Basis}

Aleskerova et al. (2018) argue that the agricultural business needs significant support for the process of resource recovery. The objective necessity of applying a loan for the reproduction of fixed assets is conditioned by the specific nature of the seasonal nature of the agricultural production process. Vasylieva (2018) writes that Ukraine's agriculture occupies a dominant global position in growing cereals and oilseeds. National exporters belong to the TOP-10 markets for wheat, barley, corn, sunflower and soybeans. Loukianova et al. (2017) write that synergies can be obtained from different sources. They identify the main types of synergy - operational and financial. Operating synergy involves improving the operating activities of companies. However, the synergy does not automatically arise after the M\&A is concluded. Businesses need to make some efforts (and some costs) to gain synergy. Xu et al. (2012) note that in a knowledge economy, organizational learning is an effective way for an enterprise to acquire, assimilate, assimilate, and apply and produce knowledge. The paper of these scholars presents a multi-level view of the organization of training, which suggests that training in organizations occurs at the individual, team, organizational and inter-organizational levels. Rajchlova et al. (2018) investigate the possible synergistic effect of the essence of accounting problems. Having identified the synergistic effect and the positive synergistic effect, the researchers focused on monitoring the positive synergistic effect of achieving positive changes in financial performance, the so-called "positive financial synergy". Zhylinska et al. (2017) propose an authors' approach to structuring synergistic effects; identify the features of synergistic interaction and identify methodological tools for evaluating the activities of diversified companies as complex integrated open- 


\section{ENTREPRENEURSHIP AND SUSTAINABILITY ISSUES}

ISSN 2345-0282 (online) http://jssidoi.org/jesi/

2020 Volume 7 Number 4 (June)

http://doi.org/10.9770/jesi.2020.7.4(12)

type structures, taking into account modern marketing management concepts. Halynska (2017) writes that given the trends of globalization and the growing competition between enterprises, the transformation processes that are currently taking place in the Ukrainian economy lead to the need for cooperation and the creation of various forms of vertical integration structures. Collaborating with one another, firms are increasingly forming alliances that open up huge opportunities for businesses.

The synergy effect is often replaced by the notion of an economic effect, which is a predictable result, and a systematically organized integration process, as opposed to a synergy effect, is predicted. Pokrason (2017) argues that the Ukrainian banking sector is faced with extremely difficult conditions, which are reflected in the national economy, a decrease in capital reserves, and a decline in the quality of lending throughout the market. The analysis of Holovach, Petrovskyi, Adamchuk (2018) showed that most European states support the policy of regulating the financial system as a holistic, indivisible phenomenon, gradually deviating from its perception as a collection of individual segments. The European Union has made a significant impact on this issue, which has introduced the integration of key functions in the regulation of the EU financial system and assigned these functions to a separate group of special bodies.

Zavadska (2018) determines that a special task for the development of the modern economy of Ukraine is to increase the role of banks in shaping the necessary resources for the implementation of innovation policy. Dzhafarova et al. (2018) write that European integration for Ukraine, on the one hand, is a way of modernizing the economy, attracting foreign investment and technology, improving the competitiveness of domestic producers, access to world markets, including the financial services market. On the other hand, it is access to world markets.

The formation of an open economy also means that the economy and financial system of the state must be internally stable, able to withstand the risks that accompany the processes of globalization and European integration. Ivanov et al. (2018) argue that it is impossible to ensure the active development of the economy, to strengthen the democratic foundations of Ukraine and to raise the standard of living of the population without the effective functioning of the credit and financial mechanism, which is a component of the banking system. Rogach et al. (2019) write that the current system of financial support for agriculture in Ukraine is on a vector of formation and adaptation to the conditions of the European Union. The EU's financial support policy for agriculture in the European Union ensures high results in agricultural production, economic and social processes and the promotion of agriculture. Rostetska, Naumkina (2019) develop the theory and practice of cooperation of Central European countries in the context of modern European integration processes, which is important for the development and implementation of foreign and domestic policy strategies in European countries and Ukraine.

Aleskerova et al. (2018) considered features of securing a loan for reproduction of fixed assets in agriculture are to take into account the sectoral specificity and structure of fixed assets and determine the types of loans that can be attracted by agricultural enterprises for the formation of resources. The conducted research shows that lending relations for reproduction of fixed assets are at the initial stage of their development. Pokrason (2017) defined the credit rating criteria for Ukrainian banks: 1) sovereign risk; 2) capital position and asset quality; 3) financing and liquidity; 4) exchange rate. Holovach (2018) have determined that government regulation of the financial system of many European countries is based on the consolidation of coordination and supervisory functions.

One or more clearly-defined bodies carry out national regulation of financial relations in such European countries as Germany, Poland, Sweden, Spain, etc. Zavadska (2018) has identified effective areas of customer interaction with banks, developing fundamentally new banking tools for investing in innovative businesses, which will help to enhance the role of banks in the innovative development of Ukraine. Rogach et al. (2019) point out that the defining feature of European financial support for agriculture is to regard it as one of the factors in the development of the European Union's financial system. In Ukraine, support for the agricultural sector formally and marginally affects the development of the agricultural sector. 


\section{ENTREPRENEURSHIP AND SUSTAINABILITY ISSUES}

ISSN 2345-0282 (online) http://jssidoi.org/jesi/

2020 Volume 7 Number 4 (June)

http://doi.org/10.9770/jesi.2020.7.4(12)

Therefore, the expediency of spreading topical forms of bank credit for agrarian structures is conditioned by destabilizing determinants in the domestic economy against the backdrop of world financial events, since it is the agro-industrial complex that addresses the issue of food security. The agro-industrial sector of the economy, considering the seasonality factor and climatic conditions, is considered especially risky from the standpoint of conservative lenders, and especially the financing of its innovation process.

At the same time, the existence of agribusiness in the gap with innovations and advanced transformations in science and technology is impossible and requires close integration into the industry. Such convergence certainly requires proper access to financial resources, which is not always self-financing and requires external borrowing.

Outlined problems of financing the innovation process in agribusiness, riskiness in particular, low investment attractiveness, specific features of the industry require the study of key trends and prerequisites for the implementation of bank lending in the system of financial support of the innovative agribusiness process in order to expand sources of access to financial resources.

\section{Methods}

During the study, the following methods were used: dialectical (Wang \& Lee (2011)), observation (Serrano-Cinca \& Gutiérrez-Nieto (2013)), critical thinking and generalization (Grishnova et al (2019); Frishammar et al (2019)) - to determine the role of the banking system in financing the development of agriculture; analysis, synthesis (Pauraa and Arhipovaa ( 2016 )) - to evaluate the potential of the banking system to finance the development of agriculture; economic and statistical method ( Lindholm-Dahlstrand, Andersson \& Carlsson (2018)) - to study the impact of macroeconomic indicators of the banking system on agriculture value added; formal and logical, systematic approach (Collewaert and Fassin (2013)) - to improve conceptual provisions and develop a conceptual model of agricultural development management using bank financing. The methods of scientific generalization, data averaging and retrospective analysis methods of financing sources of agribusiness innovations of Ukraine were also used in the article.

The theoretical and methodological basis of the research is the scientific works of representatives of different schools and areas of economic theory, modern scientific developments of domestic and foreign scientists, devoted to the issues of synergy, synergetic effect and their manifestation and measurement in integration processes.

The methodological basis of the study was the systematic and integrated approaches to the study of the synergistic effect in integration processes (see Figure 1). 


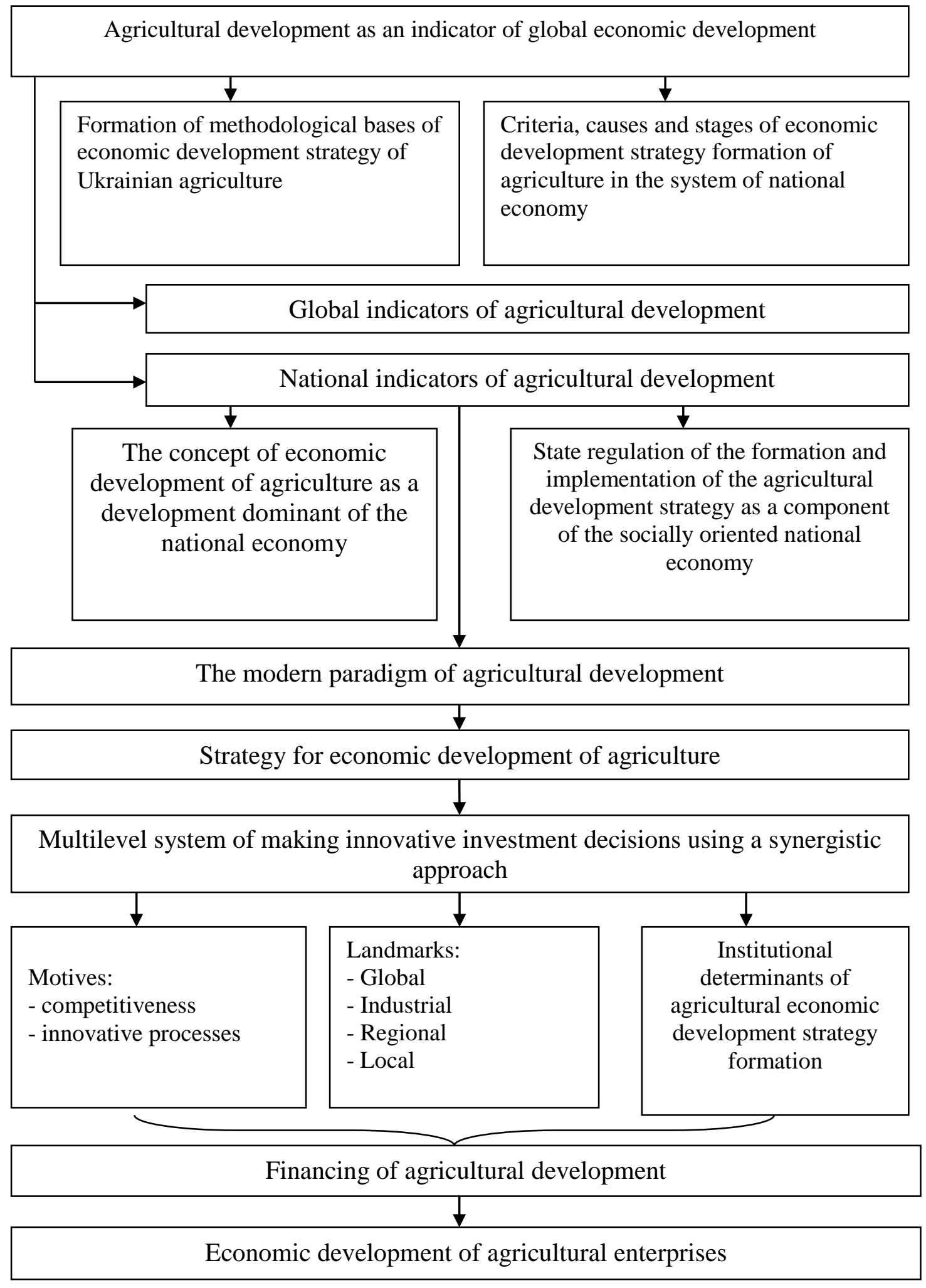

Fig. 1. The logic of the study 
Together with the interdisciplinary nature of the synergistic approach, its transdisciplinarity is important. It reveals itself in such synergistic features as operation "through", disciplinary boundaries in the study of the subject, as going "beyond" specific disciplines. The transdisciplinary features of the synergistic approach are manifested in the ability to transfer cognitive schemas from one subject area to another with the emergence of shared spaces of existence. The transdisciplinary nature of synergetics creates an anthropic space for the dialogical communication of subjects. From this point of view, synergetics reveals the researcher's territory of subjectivity.

The key provisions of the synergistic methodology are as follows:

- complex systems cannot impose development paths, but need to promote their own development trends (Anning-Dorson, Nyamekye \& Odoom 2017);

- chaos can be a constructive source, from which a new organization of the system may be born (Holovach, Petrovskyi and Adamchuk 2018);

- at certain moments of instability, small perturbations can have macro-consequences and develop into macrostructures, in particular, the actions of one particular personality can affect macro-social processes (Vasylieva 2018.; Paptsov, Nechaev and Mikhailushkin 2019);

- for complex systems there are several alternative ways of development, but at certain stages of evolution a certain pre-determination of the deployment of processes manifests itself, and the present state of the system is determined not only by its past but also by its future (Loukianova, Nikulin and Vedernikov (2017));

- a complexly organized system involves not only simpler structures and is not an ordinary sum of parts, but generates structures of all ages in a single world (Halynska (2017));

- taking into account the regularities and conditions of the rapid, avalanche-like processes and processes of nonlinear self-development of systems, it is possible to initiate these processes through human administrative actions (Laila and Widihadnanto 2017).

\section{Results}

According to the analysis of the Global Innovation Index (GII), which takes into account about 80 criteria and allows annual monitoring of innovative activity of countries, the rating of innovative activity of Ukraine in the world is also gradually increasing (Fig. 2).

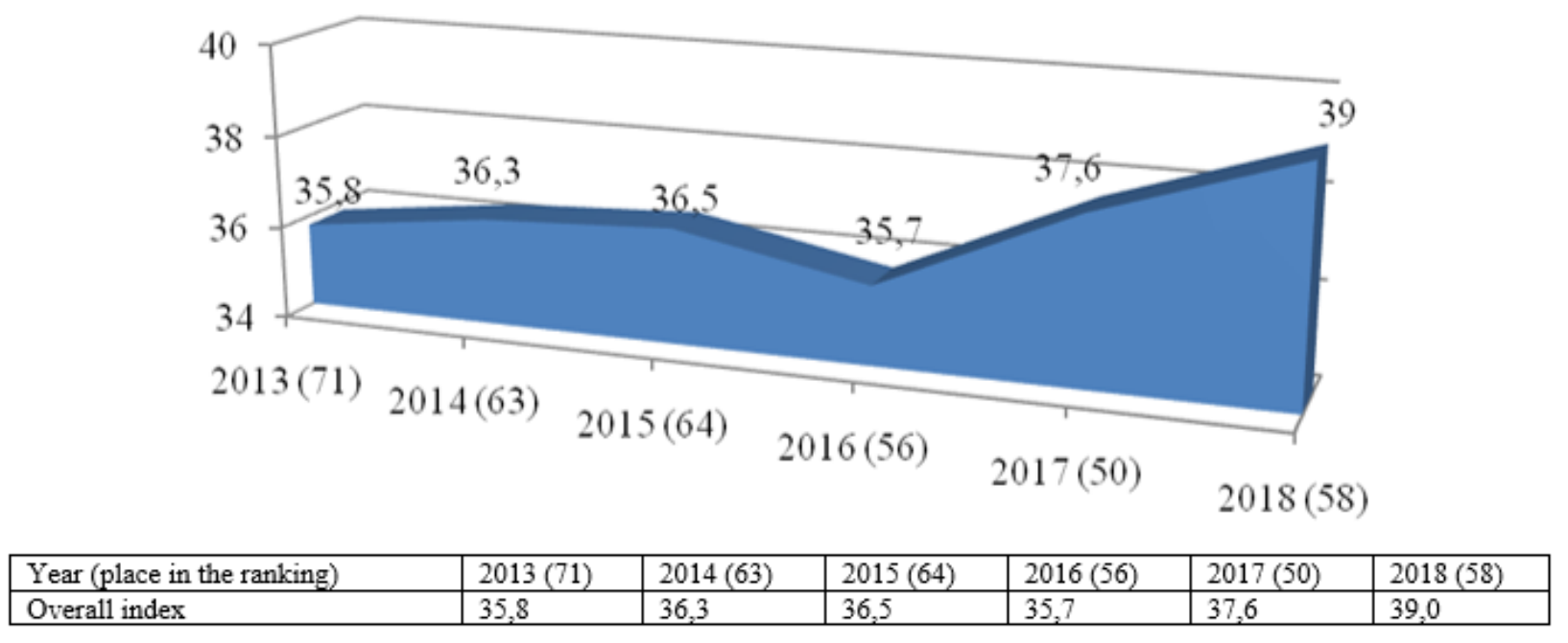

Fig. 2. Dynamics of the Global Innovation Index and Ukraine place in the World Ranking for the period 2013-2018 Source: compiled by authors based on World Bank, World Economic Forum data 


\section{ENTREPRENEURSHIP AND SUSTAINABILITY ISSUES}

ISSN 2345-0282 (online) http://jssidoi.org/jesi/

2020 Volume 7 Number 4 (June)

http://doi.org/10.9770/jesi.2020.7.4(12)

For a more detailed explanation of the topic of the study, it was considered the dynamics of banking lending to the agrosphere. Financing of the innovation process of the agro-industrial complex of Ukraine is carried out exclusively at the expense of the own financial resources of the enterprises (Table 1).

Table 1. Dynamics and structure of financing sources of agribusiness innovations, 2010-2018.

\begin{tabular}{|c|c|c|c|c|c|}
\hline \multirow{2}{*}{\multicolumn{2}{|c|}{ Years }} & \multirow{2}{*}{ Total } & \multicolumn{3}{|c|}{ Including the expense of funds } \\
\hline & & & own funds & state budget funds & credits \\
\hline \multirow{2}{*}{2010} & thousand UAH & 64917,8 & 64407,8 & - & 510 \\
\hline & in a percentage of the total & 100 & 99,2 & - & 0,8 \\
\hline \multirow{2}{*}{2011} & thousand UAH & 85140,2 & 85140,2 & - & - \\
\hline & in a percentage of the total & 100 & 100 & - & - \\
\hline \multirow{2}{*}{2012} & thousand UAH & 75878,4 & 70726,3 & 2828,1 & 2324 \\
\hline & in a percentage of the total & 100 & 93,2 & 3,7 & 3,1 \\
\hline \multirow{2}{*}{2013} & thousand UAH & 72241,9 & 72017,9 & - & 224 \\
\hline & in a percentage of the total & 100 & 99,7 & - & 0,3 \\
\hline \multirow{2}{*}{2014} & thousand UAH & 67225,9 & 67225,9 & - & - \\
\hline & in a percentage of the total & 100 & 100 & - & - \\
\hline \multirow{2}{*}{2015} & thousand UAH & 85533,9 & 85533,9 & - & - \\
\hline & in a percentage of the total & 100 & 100 & - & - \\
\hline \multirow{2}{*}{2016} & thousand UAH & 92742,6 & 92742,6 & - & - \\
\hline & in a percentage of the total & 100 & 100 & - & - \\
\hline \multirow{2}{*}{2017} & thousand UAH & 103712,5 & 103712,5 & - & - \\
\hline & in a percentage of the total & 100 & 100 & - & - \\
\hline \multirow{2}{*}{2018} & thousand UAH & 112776,5 & 112776,5 & - & - \\
\hline & in a percentage of the total & 100 & 100 & - & - \\
\hline
\end{tabular}

Source: based on data from the Ministry of Agrarian Policy and Food of Ukraine

The state budget is (3.7\% in 2012) and lending is (0.8\% - in 2010, 3.1\% - in 2012, 0.3\% - in 2013). Such a structure of financial support hinders the innovative activity of the industry, since its own funds are directed mainly to the modernization of existing equipment, not to the creation of new ones.

It was considered the potential of the banking system to finance the development of agriculture. The study of innovative economic processes and the identification of reserves for the effective use of financial instruments, the increase in production of goods, works and services occur after the implementation of the cycle of financial resources. They provide an opportunity to improve the work in the future, but do not affect the mistakes, miscalculations and all kinds of illegal actions that took place in the analyzed period. While exercising the control function is not so much about detecting deviations from a given state of an object, it is about preventing them from occurring.

Assessing the feasibility of using a financial instrument at the stage of innovation in agriculture prevents those processes that are contrary to the requirements of regulatory documents or do not agree with the purpose of innovation. Accordingly, control is a means of preventively regulating innovation in agriculture, which causes positive or unwanted changes in management. However, these management functions, with the skillful use of their interpenetration, reveal a real picture of the managed system. It follows that, knowing the content of managing the bank financing of the national economy, it is possible to effectively manage the development of innovative agriculture. In fig. 3 it is developed a conceptual model for making innovative investment decisions in different sectors of the national economy using a synergistic approach. 


\begin{tabular}{|c|c|c|c|c|c|}
\hline \multirow{3}{*}{$\begin{array}{l}\text { Goal, task, strategy of } \\
\text { management }\end{array}$} & \multicolumn{2}{|c|}{ Development of management content } & \multicolumn{3}{|c|}{ Development of management form } \\
\hline & 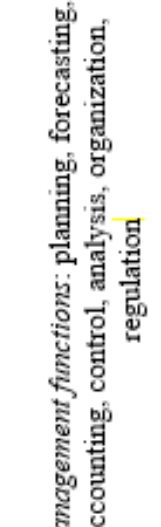 & 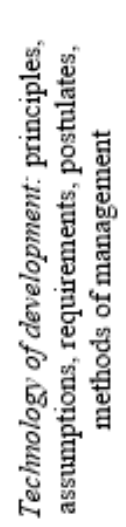 & 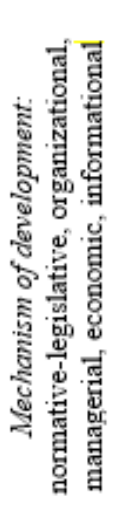 & 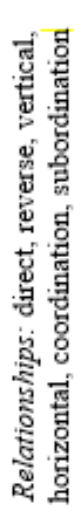 & 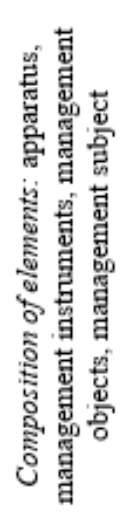 \\
\hline & \multicolumn{5}{|c|}{ Management structure } \\
\hline Development directions & \multirow{2}{*}{\multicolumn{5}{|c|}{ Management development process in innovative business environment }} \\
\hline Tools & \multicolumn{2}{|c|}{ Evaluation of synergy effects } & & & \\
\hline
\end{tabular}

Fig. 3. Conceptual model of making innovative investment decisions in different sectors of the national economy using a synergistic approach

Source: developed by authors

In Table 2 the financial sustainability indicators of the Ukrainian banking system are analyzed.

Table 2. Indicators of financial stability of the banking system of Ukraine, mln. UAH

\begin{tabular}{|c|c|c|c|c|c|c|c|}
\hline Indicator & 2013 & 2014 & 2015 & 2016 & 2017 & 2018 & $\begin{array}{l}\text { The ratio of } \\
2018 \text { to } 2013\end{array}$ \\
\hline $\begin{array}{l}\text { The ratio of regulatory capital to risk-weighted } \\
\text { assets }\end{array}$ & 18,26 & 15,60 & 12,31 & 12,69 & 16,10 & 16,18 & 88,61 \\
\hline $\begin{array}{l}\text { The ratio of non-performing loans to total } \\
\text { gross loans }\end{array}$ & 12,89 & 18,98 & 28,03 & 30,47 & 54,54 & 52,85 & 410,01 \\
\hline Share in total gross loans: Residents & 98,72 & 96,05 & 94,54 & 95,92 & 94,21 & 93,47 & 94,68 \\
\hline Share in total gross loans: Non-residents & 1,28 & 3,95 & 5,46 & 4,08 & 5,79 & 6,53 & 510,16 \\
\hline The rate of return on assets & 0,26 & $-4,24$ & $-5,54$ & $-12,47$ & $-1,76$ & 1,60 & 615,38 \\
\hline The rate of return on capital & 1,72 & $-31,95$ & $-65,5$ & $-122,1$ & $-15,34$ & 14,61 & 849,42 \\
\hline The ratio of interest margin to gross income & 58,56 & 48,46 & 39,00 & 45,94 & 50,20 & 52,02 & 88,83 \\
\hline The ratio of liquid assets to total assets & 20,63 & 26,40 & 33,00 & 48,53 & 53,94 & 51,14 & 247,89 \\
\hline
\end{tabular}

Source: compiled by the National Bank of Ukraine

In Fig. 4 the dynamics of agriculture, value added (\% of GDP) and employment in agriculture (\% of total employment) are analyzed. 


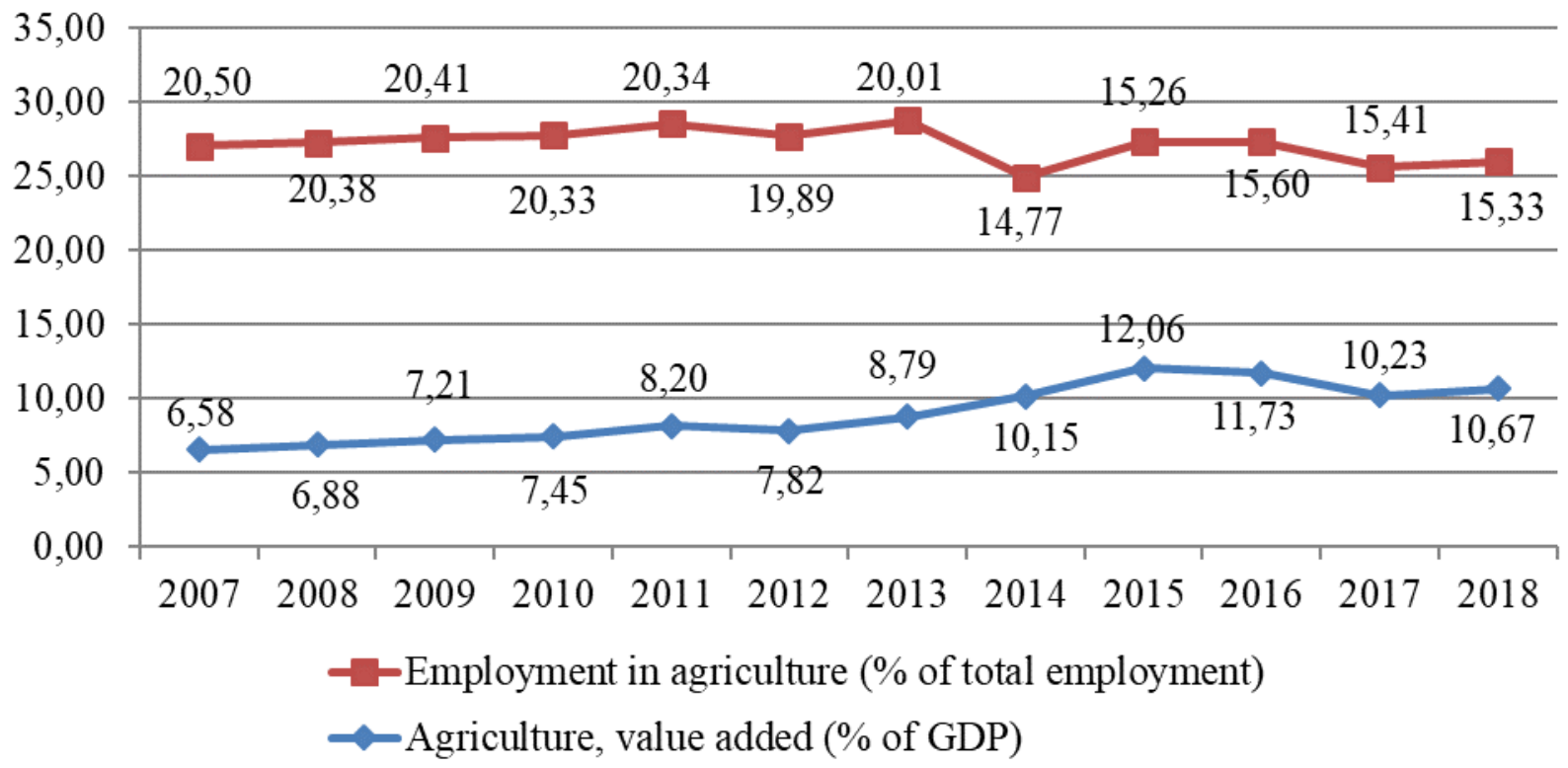

Fig. 4. Dynamics of agriculture, value added (\% of GDP) and employment in agriculture (\% of total employment) Source: compiled by the National Bank of Ukraine

For more detailed disclosure of the research topic, the multiple regression model was applied. Most economic factors are often influenced by more than one factor. Thus, agriculture value added (\% of GDP) is determined not only by the volume of credit support of the agro-industrial complex of Ukraine by the banking system, but also by the number of operating structural units of banks, employment in agriculture and many other factors. The data for the analysis are taken for 2013-2018. For research it was applied the multiple regression method.

$$
\hat{y}=f\left(x_{1}, x_{2}, \ldots, x_{p}\right)
$$

Multiple regression is widely used in macroeconomic calculations. The main goal of multiple regression is to create a model with a large number of factors, as well as to determine the influence of each factor separately and their combined effect on the modeled indicator. It was used the linear model of multiple regression for research:

$$
y=\alpha^{\prime}+\beta_{1}^{\prime} x_{1}+\beta_{2}{ }^{\prime} x_{2}+\ldots+\beta_{p}{ }^{\prime} x_{p}+\varepsilon
$$

After the calculations, the function $y$ agriculture value added (\% of GDP) is characterized by equation:

$$
y=38+0,09 x_{1}+0,11 x_{2}+0,06 x_{3}+\varepsilon
$$

where the factors are:

$\mathrm{x} 1$ - the volume of credit support of the agro-industrial complex of Ukraine by the banking system (million UAH.),

$\mathrm{x} 2$ - number of operating structural units of banks (thousand units),

$\mathrm{x} 3$ - employment in agriculture (\%).

It is understandable that with the constant number of operating structural units of banks and employment in agriculture, the growth of the volume of credit support of the agro-industrial complex of Ukraine by the banking system by 1 million UAH entails an increase in agricultural value added by an average of $0.09 \%$. The increase in the number of operating structural units of banks with constant volumes of credit support of the agro-industrial complex of Ukraine and employment in agriculture, leads to an increase in agricultural value added on average by 
$0.11 \%$. With unchanged volumes of credit support of the agro-industrial complex of Ukraine and the number of operating structural units of banks, the growth of employment in agriculture leads to an increase in agricultural value added by an average of $0.06 \%$. However, this does not mean that the agricultural value added is more influenced by the first factor than the second and the third. Using the regression equation on a standardized scale, it is possible to make the following comparison. The standardized regression equation looks like this:

$$
\hat{t}_{y}=0,8 t_{x_{1}}+0,3 t_{x_{2}}+0,5 t_{x 3}
$$

This means that with the growth of the first factor by one unit, with a constant number of operating structural branches of banks, employment in agriculture and agricultural value added increase by an average of $0.8 \%$. Since $\beta_{1}>\beta_{2}>\beta_{3}(0,8>0,3>0,5)$, it can be concluded that the first factor has a greater influence on the agricultural value added rather than the second factor, as it seems from the full-scale regression equation.

In Fig. 5 the sources and effects of synergy in a multilevel system of making innovative investment decisions using a synergistic approach are considered.

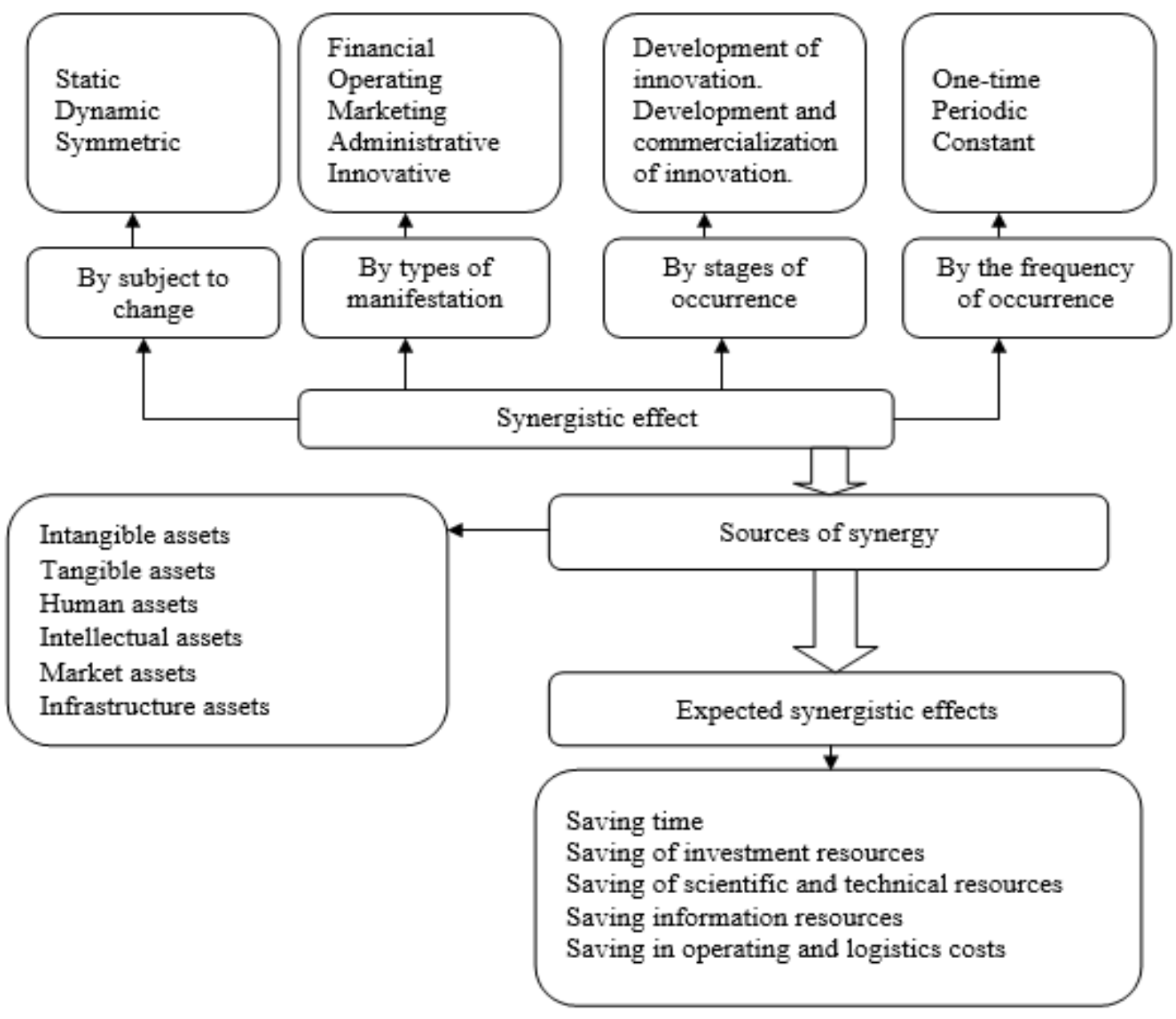

Fig. 5. Sources and effects of synergy in a multilevel innovative investment decision making system using a synergistic approach Source: own development 
Direct proportional dependence causes consideration of the basic processes and their changes on the basis of systems of differential linear equations, the solution of which is based on the use of mathematical analysis apparatus and is obtained depending on the initial conditions in real and complex values.

A multilevel system of making innovative investment decisions using a synergistic approach is used to identify the forms of dependencies that cause this or that trend, since the decisions can be many.

The existence of multi-directional links over time can lead to the aggregation into new forms (cooperation, integration, coalition) and the formation of links with more potential.

From the point of view of the synergistic approach, economic systems are represented as a set of many subsystems, characterized by incompleteness of information and the following features: nonlinearity (loss of the property of additivity in the process of development); instability (loss of equilibrium states in the process of evolution); openness (exchange of resources from the outside); subordination (functioning and development are determined by processes in subsystems).

The following synergistic effects are distinguished: the effect of introducing (accessing) new products and markets and the effect of further compatible strategic steps of the partners.

In Fig. 6 the advantages and contradictions of making innovative investment decisions using a synergistic approach are considered. 
ISSN 2345-0282 (online) http://jssidoi.org/jesi/

2020 Volume 7 Number 4 (June)

http://doi.org/10.9770/jesi.2020.7.4(12)

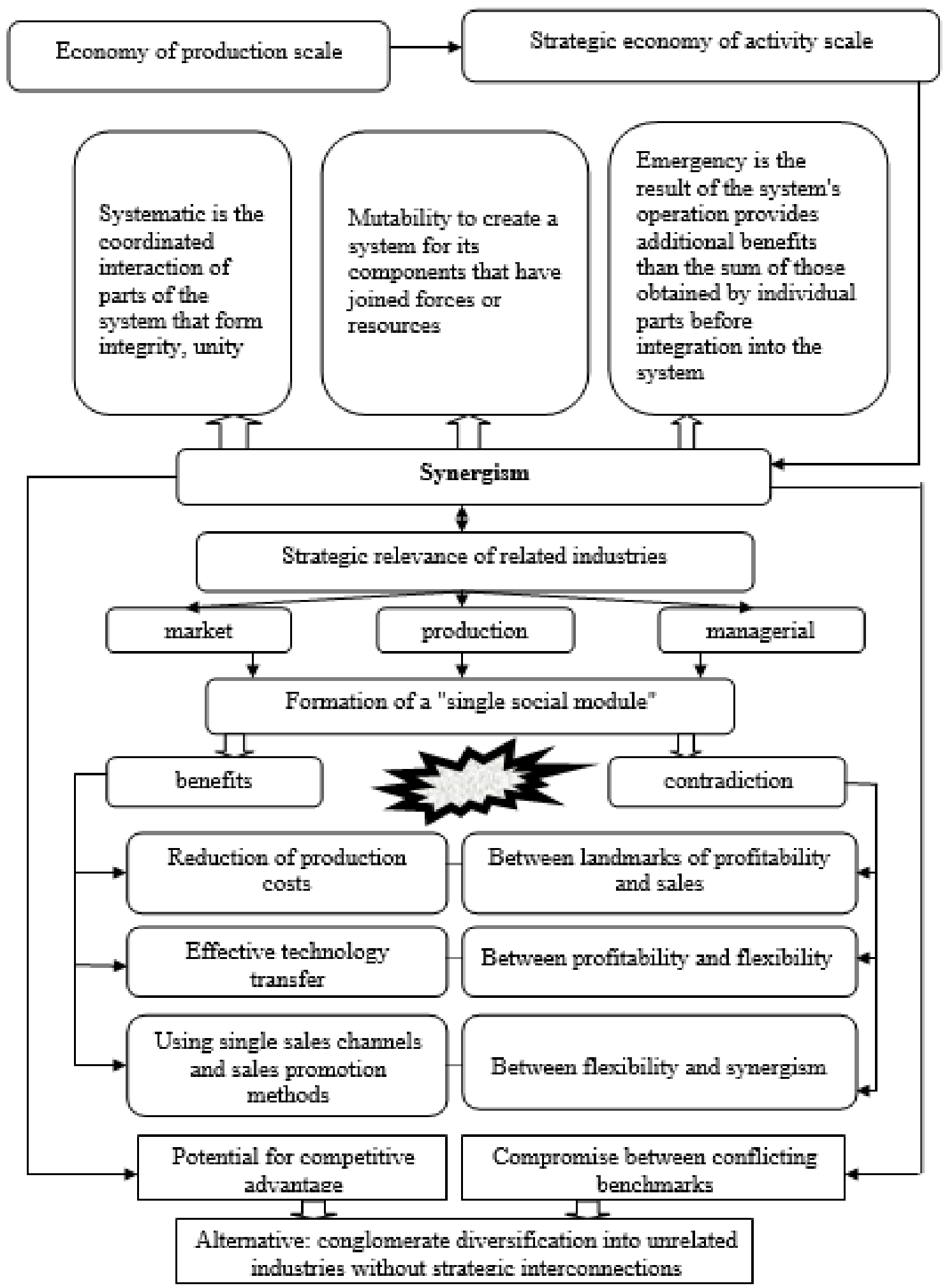

Fig. 6. Advantages and contradictions of making innovative investment decisions using a synergistic approach Source: own design 
ENTREPRENEURSHIP AND SUSTAINABILITY ISSUES

ISSN 2345-0282 (online) http://jssidoi.org/jesi/

2020 Volume 7 Number 4 (June)

http://doi.org/10.9770/jesi.2020.7.4(12)

Thus, the potential for the development of economic systems lies in the possibility of their self-organization, the realization of which occurs in cases of inertia of motion. The use of a multi-level system of making innovative investment decisions using a synergistic approach generates a synergistic potential, capable of finding many possible solutions for the trajectory of sustainable development (see Table 3).

Table 3. An explanatory table illustrating the achievement of the study goals

\begin{tabular}{|c|c|c|c|}
\hline Goal & Previous researches & The obtained results & Future researches \\
\hline $\begin{array}{l}\text { Generalization of synergetic } \\
\text { concept components and } \\
\text { revealing of peculiarities of } \\
\text { economic systems development } \\
\text { on the basis of system approach } \\
\text { and general systems theory. }\end{array}$ & $\begin{array}{l}\text { Kanbur (2019); Gai and } \\
\text { Kapadia (2019) argue that the } \\
\text { most real world crises are } \\
\text { located between extreme } \\
\text { indicators of pure illiquidity and } \\
\text { net insolvency, and instruments } \\
\text { of the solvency and liquidity } \\
\text { crisis need to be carefully } \\
\text { weighed in the development of } \\
\text { anti-crisis policy. }\end{array}$ & $\begin{array}{l}\text { The synergistic concept } \\
\text { contributes to the knowledge of } \\
\text { such complex, non-linear, open } \\
\text { systems as the global economy, } \\
\text { society, people and their } \\
\text { activities. When applying the } \\
\text { ideas of synergetics in } \\
\text { agricultural financing, one } \\
\text { limitation should be taken into } \\
\text { account: the theory of financing } \\
\text { is not a theory of development, } \\
\text { because the main question } \\
\text { remains - the sources of } \\
\text { financing. }\end{array}$ & $\begin{array}{l}\text { What are the different roles of } \\
\text { the synergistic concept in } \\
\text { transformational change? }\end{array}$ \\
\hline $\begin{array}{l}\text { Analysis of the current state of } \\
\text { financing of the agro-industrial } \\
\text { complex by the banking } \\
\text { institutions, submission of } \\
\text { proposals for further effective } \\
\text { financing of enterprises of the } \\
\text { agricultural sector of the } \\
\text { Ukrainian economy based on } \\
\text { synergistic effect. }\end{array}$ & $\begin{array}{l}\text { Jarkinbayev and Kosherbayeva } \\
(2018) \text { write that the accuracy } \\
\text { and consistency of } \\
\text { macroeconomic projections are } \\
\text { of particular importance to } \\
\text { developing countries, which are } \\
\text { significantly influenced by } \\
\text { external factors and } \\
\text { macroeconomic shocks. }\end{array}$ & $\begin{array}{l}\text { According to the theory of } \\
\text { synergetics, no open system can } \\
\text { impose a mode of behavior or } \\
\text { development, but one can } \\
\text { choose and stimulate one of the } \\
\text { conditions laid down in specific } \\
\text { conditions, counting not so } \\
\text { much on a managerial, but on a } \\
\text { synergetic, self-managed } \\
\text { process. }\end{array}$ & $\begin{array}{l}\text { Assessment of other factors is a } \\
\text { topic for future research. }\end{array}$ \\
\hline $\begin{array}{l}\text { Consideration of the innovation- } \\
\text { investment process as a source } \\
\text { of synergy formation, which } \\
\text { creates preconditions for the } \\
\text { potential of self-organization } \\
\text { and reproduction of cycles of } \\
\text { the real sector of the economy. }\end{array}$ & $\begin{array}{l}\text { Amoro et al (2019) argue that if } \\
\text { developing countries do not } \\
\text { make the promotion of } \\
\text { productive entrepreneurship a } \\
\text { major concern in their political } \\
\text { agendas, they will only diminish } \\
\text { efforts without achieving higher } \\
\text { results. }\end{array}$ & $\begin{array}{l}\text { Innovation and investment } \\
\text { processes are based on the laws } \\
\text { and patterns of self-organization } \\
\text { and self-development of } \\
\text { economic systems. They give an } \\
\text { opportunity to take a new } \\
\text { approach to the development of } \\
\text { problems of agricultural } \\
\text { development, considering them } \\
\text { primarily from the point of view } \\
\text { of openness, co-creation and } \\
\text { orientation to development. }\end{array}$ & $\begin{array}{l}\text { How is the innovation and } \\
\text { investment process changing in } \\
\text { different technological sectors } \\
\text { over a long period of time? }\end{array}$ \\
\hline
\end{tabular}




\section{ENTREPRENEURSHIP AND SUSTAINABILITY ISSUES}

ISSN 2345-0282 (online) http://jssidoi.org/jesi/

2020 Volume 7 Number 4 (June)

http://doi.org/10.9770/jesi.2020.7.4(12)

\section{Discussion}

We are expanding the research of scholars such as Gai and Kapadia (2019) who find that liquidity crises affect solvency prospects; and the expected recovery ratios of the creditors, in turn, will affect the short-term prospect of a liquidity decision. We, for more detailed disclosure of the research topic, study the dynamics of development of banking lending to the agrosphere and financing the innovation process of the agro-industrial complex of Ukraine. This allows us to capture the interaction between the specific features of the country and the possibilities of financing agriculture. So, Kanbur (2019) notes that the analysis of unevenness in the country is important for establishing the basic facts of unevenness in a world where countries are increasingly linked by trade and investment and where, the global economy requires an assessment of global inequality rather than national inequality in isolation. We contribute to our existing research activities by analyzing the Global Innovation Index (GII), which takes into account about 80 criteria and allows us to track the innovative activity of countries and the rating of innovative activity of Ukraine in particular on a yearly basis.

Deloof, La Rocca and Vanacker (2019) provide new theoretical and empirical insights into how heterogeneity in the local banking market affects funding. And in our study, we continue and expand on this topic by considering the potential of the banking system to finance the development of agribusiness.

In their work, Grishnova, Cherkasov and Brintseva (2019) have obtained empirical results that confirm theoretical hypotheses about the dynamic changes in the social sphere and employment and society in general; and the world at large, the public administration of each individual country and every real or potential employee, in particular, must prepare thoroughly for this. And as we deepen the proposed topic, we study the impact on agriculture of value added (\% of GDP) of the volume of credit support of the agro-industrial complex of Ukraine by the banking system, the number of operating structural units of banks, employment in agriculture. Amoro, Ciravegna, Mandakovic, and Stenholm (2019) argue that developing countries should rationally organize their functions, improve governance and eliminate barriers that impede productive business activity rather than focus only on reducing unemployment. Our research shows that with constant volumes of credit support of the agro-industrial complex of Ukraine and the number of operating structural units of banks, growth in employment in agriculture leads to an increase in agricultural value added by an average of $0.06 \%$.

Jarkinbayev and Kosherbayeva (2018) argue that monetary forecasting errors during the review have increased and a possible reason for this is the lack of coordination between the Ministry of National Economy, Ministry of Finance and the National Bank in the preparation of macroeconomic forecasts. And in our study, in turn, the conceptual model of making innovation-investment decisions in different branches of the national economy using a synergistic approach is proposed.

The analysis and research of the tendencies characterizing the state of credit of the agro-industrial complex in Ukraine made it possible to conclude that bank loans are not able to fully meet the needs of agricultural enterprises for credit resources; regulation of credit provision for agricultural enterprises is ineffective and government support is inadequate; unsatisfactory volumes of credit inflows into the agricultural sector due to harsh conditions and high interest rates.

The study also found that globalization and concentration of production are now taking place in all sectors of the economy. They qualitatively and quantitatively affect both the individual enterprise and the economy of the state as a whole. The solution to these problems is complicated by the fact that the functioning of the Ukrainian economy is characterized by a number of fundamental contradictions.

Methodological and methodological limitations of the study are that when assessing economic cyclicality, its synergistic nature is taken into account, which has a significant impact on the features of cyclical dynamics in real 


\section{ENTREPRENEURSHIP AND SUSTAINABILITY ISSUES}

ISSN 2345-0282 (online) http://jssidoi.org/jesi/

2020 Volume 7 Number 4 (June)

http://doi.org/10.9770/jesi.2020.7.4(12)

economic systems. The nonlinearity and complexity that characterize the economic system, as well as the presence of a large number of feedbacks, determine the synergistic nature of many economic phenomena and lead to numerous synergistic effects that change the qualitative side of the functioning of the national economy. Understanding the nature and features of the manifestation of synergistic effects allows you to organize the management of the economy at a new level, based on the ideas of discretion and stability of trajectories of economic development. The presence of synergistic effects in the economy requires new approaches to forecasting, planning, and regulation at different levels - from the economy of an individual firm to the economy of the whole country.

Prospects for further research are to study non-linear processes of formation and development of institutional systems, to find ways to form and actualize their market potential.

\section{Conclusion}

The conducted research has shown that, a multi-level system of making innovative investment decisions using a synergistic approach is necessary to identify and build up a positive synergistic effect from the combination and interaction of assets and sources of financing, evaluation of the end results of such interaction, cooperation of labor, integration of industries, production integration.

For example, the banking system financing of the agrarian sector of the economy in Ukraine was considered. The research showed that with the constant number of operating structural branches of banks and employment in agriculture, the growth of the credit support volume of the agro-industrial complex of Ukraine by the banking system by 1 million UAH entails an increase in agricultural value added by an average of $0.09 \%$. The increase in the number of operating structural branches of banks with constant volumes of credit support of the agroindustrial complex of Ukraine and employment in agriculture, leads to an increase in agricultural value added on average by $0.11 \%$. With unchanged volumes of credit support of the agro-industrial complex of Ukraine and the number of operating structural branches of banks, the growth of employment in agriculture leads to an increase in agricultural value added by an average of $0.06 \%$. It is proved that the factor of the volume of credit provision of the agro-industrial complex in Ukraine has the largest influence on agricultural value added by banking system among other investigated factors.

The practical significance of the conducted research is that the scientific developments will allow forming in Ukraine an effectively functioning agro-industrial complex with optimal financing on the basis of the use of a multi-level system of making innovative investment decisions using a synergistic approach.

Further researches are in the field of studying of system-forming factors and regularities of behavior of economic systems in the conditions of synergy potential restoration.

\section{References:}

Ahmed, S.M., Ansari, M.I. 2018. Financial Sector Development and Economic Growth: the South-Asian Experience. Journal of Asian Economics, 3(9), pp. 503 - 517. https://doi.org/10.1016/S1049-0078(99)80100-6

Aleskerova Yu., Fedoryshyna L., Koval N. 2018 Features of loan security for the reproduction of fixed assets for agricultural purposes. Baltic Journal of Economic Studies, 4(4), pp. 1-5. https://doi.org/10.30525/2256-0742/2018-4-4-1-5 


\section{ENTREPRENEURSHIP AND SUSTAINABILITY ISSUES}

ISSN 2345-0282 (online) http://jssidoi.org/jesi/

2020 Volume 7 Number 4 (June)

http://doi.org/10.9770/jesi.2020.7.4(12)

Amoro, J.E. Ciravegna, L., Mandakovic, V., Stenholm, P. 2019. Necessity or Opportunity? The Effects of State Fragility and Economic Development on Entrepreneurial Efforts, Entrepreneurship Theory and Practice, 43(4), pp. 725-750 https://doi.org/10.1177/1042258717736857

Anning-Dorson, T., Nyamekye, M. B. \& Odoom, R. 2017. Effects of regulations and competition on the innovativeness-performance relationship: Evidence from the financial services industry. International Journal of Bank Marketing, 35(6), pp. 925-943, https://doi.org/10.1108/IJBM-06-2016-0079

Barnett, W. A., Wang, C., Wang, X., Wu, L. 2019. What inflation measure should a currency union target?, Journal of Macroeconomics 59(C), pp. 123-139. http://dx.doi.org/10.1016/j.jmacro.2018.11.006

Belas, J., Gavurova, B., Kocisova, K., Delibasic, M. 2018. The Relationship between Asset Diversification and The Efficiency of Banking Sectors in EU Countries, Transformations in Business \& Economics, 17, 3C(45C), pp. 479-496.

Brix-Asala, C., Hahn, R., Seuring, S. 2016. Reverse logistics and informal valorisation at the Base of the Pyramid: A case study on sustainability synergies and trade-offs, European Management Journal, 34 (4), pp. 414-423, https://doi.org/10.1016/j.emj.2016.01.004

Calvo-Mora, A. Navarro-García, A. Rey-Moreno, M. Periañez-Cristobal, R. 2016. Excellence management practices, knowledge management and key business results in large organisations and SMEs: A multi-group analysis, European Management Journal, 34 (6), pp. 661-673 https://doi.org/10.1016/j.emj.2016.06.005

Chulkova, G.V., Semchenkova, S.V., Zarankina O.M. 2017. Agricultural investment opportunities within the region: risks and development strategies, International Agricultural Journal, 60(2), pp.1-7.

Cobeña, M., Gallego, A., Casanueva, C. 2017. Heterogeneity, diversity and complementarity in alliance portfolios, European Management Journal, 35(4), pp. 464-476 https://doi.org/10.1016/j.emj.2016.12.005

Collewaert, V., Fassin, Y. 2013. Conflicts between entrepreneurs and investors: the impact of perceived unethical behavior. Small Business Economics, 40, pp. 635-649. https://doi.org/10.1007/s11187-011-9379-7

Deloof, M., La Rocca, M., Vanacker, T. 2019. Local Banking Development and the Use of Debt Financing by New Firms, Entrepreneurship Theory and Practice, 43(6), pp. 1250-1276. https://doi.org/10.1177/1042258718783486

Dzhafarova, O., Riabchenko, O., Artemenko, I. 2018. Structural and legal analysis of banking safety in Ukraine. Baltic Journal of Economic Studies, 4(5), pp. 67-74. https://doi.org/10.30525/2256-0742/2018-4-5-67-74

Frishammar, J. Richtnér, A. Brattström, A. Magnusson, M. Björk, J. 2019. Opportunities and challenges in the new innovation landscape: Implications for innovation auditing and innovation management. European Management Journal, 37(2), pp. 151-164 https://doi.org/10.1016/j.emj.2018.05.002

Gai, P., Kapadia, S. 2019. Networks and systemic risk in the financial system, Oxford Review of Economic Policy, 35(4), pp. 586-613.

Grishnova O., Cherkasov A. and Brintseva O. 2019. Transition to a new economy: transformation trends in the field of income and salary functions. Problems and Perspectives in Management, 17(2), pp. 18-31. https://doi.org/10.21511/ppm.17(2).2019.02

Hallberg, N.L., Brattström, A. 2019. Concealing or revealing? Alternative paths to profiting from innovation. European Management Journal, 37(2), pp. 165-174. https://doi.org/10.1016/j.emj.2018.04.003

Halynska, Yu. 2017. Emergence of synergetic effect in creation of collaborative alliances in natural resource management. Environmental Economics, 8(3), pp. 150-156. https://doi.org/10.21511/ee.08(3-1).2017.07

Holovach, A., Petrovskyi, A., Adamchuk, O. 2018. Administrative and legal principles of the functioning of the financial system in Ukraine and European countries: a comparative analysis. Baltic Journal of Economic Studies, 4(1), pp. 77-84. https://doi.org/10.30525/2256-0742/2018-4-1-77-84

Ivanov, S., Hromenko, Yu., Rodina V. 2018. Problems of banking legal relationships. Baltic Journal of Economic Studies, 4(5), pp. 94-99 https://doi.org/10.30525/2256-0742/2018-4-5-94-99

Jarkinbayev, Zh. and Kosherbayeva, A. 2018. Problems in evaluating accuracy and consistency of macroeconomic forecasts. Problems and Perspectives in Management, 16(2), pp. 102-112. https://doi.org/10.21511/ppm.16(2).2018.10 


\section{ENTREPRENEURSHIP AND SUSTAINABILITY ISSUES}

ISSN 2345-0282 (online) http://jssidoi.org/jesi/

2020 Volume 7 Number 4 (June)

http://doi.org/10.9770/jesi.2020.7.4(12)

Kanbur, R. 2019. Inequality in a global perspective, Oxford Review of Economic Policy, 35(3), pp. 431-444, https://doi.org/10.1093/oxrep/grz010

Khalatur, S., Zhylenko, K., Masiuk, Yu., Velychko, L. and Kravchenko M. 2018. Assessment of bank lending diversification in Ukraine. Banks and Bank Systems, 13(3), pp. 141-150. https://doi.org/10.21511/bbs.13(3).2018.14

Lindholm-Dahlstrand, A., Andersson, M., Carlsson, B. 2018. Entrepreneurial experimentation: a key function in systems of innovation, Small Business Economics, 53, pp. 591-610

Loukianova, A., Nikulin, E. and Vedernikov, A. 2017. Valuing synergies in strategic mergers and acquisitions using the real options approach, Investment Management and Financial Innovations, 14(1-1), pp. 236-247. https://doi.org/10.21511/imfi.14(1-1).2017.10

Materials of the official website of the Ministry of Agrarian Policy and food of Ukraine. Retrieved from www.minagro.gov.ua [in Ukrainian]

Materials of the official website of the National Bank of Ukraine. Retrieved from https://www.bank.gov.ua [in Ukrainian]

Materials of the official website of the State Statistics Committee. Retrieved from https://www.ukrstat.gov.ua [in Ukrainian]

Pauraa, L., Arhipovaa, I. 2016. Analysis of the milk production and milk price in Latvia, Procedia Economics and Finance, 39, pp. 39-43 https://doi.org/10.1016/S2212-5671(16)30238-6

Pokrason, S. 2017 A healthy dose of pessimism? Influence of the Ukrainian economy on its banking sector credit ratings. Baltic Journal of Economic Studies, 3(4), pp. 216-223.

Rajchlova, Ja., Fedorova, A., Somerlikova, K., Grega, L. and Svatošová, V. (2018). Assessing the existence of synergistic effect in the consolidated accounting entities in the Czech Republic. Investment Management and Financial Innovations, 15(2), pp. $305-316$. https://doi.org/10.21511/imfi.15(2).2018.27

Rogach, S., Vdovenko, L., Polishchuk, O. 2019, Agriculture of Ukraine under the joint policy of the European Union, Baltic Journal of Economic Studies, 5(3), pp. 178-183 https://doi.org/10.30525/2256-0742/2019-5-3-178-183

Rostetska, S., Naumkina, S. 2019. Paradigms of European integration processes in the EU, visegrád group, and Ukraine, Baltic Journal of Economic Studies, 5(3), pp. 184-192. https://doi.org/10.30525/2256-0742/2019-5-3-184-192

Serrano-Cinca, C. \& Gutiérrez-Nieto, B. (2013) A decision support system for financial and social investment, Applied Economics, 45(28), pp. 4060-4070. https://doi.org/10.1080/00036846.2012.748180

Shin-Yun Wang \& Cheng-Few Lee (2011). Fuzzy multi-criteria decision-making for evaluating mutual fund strategies, Applied Economics, 43(24), pp. 3405-3414. https://doi.org/10.1080/00036841003636318

The World Bank. 2018. World Development Indicators. Retrieved from: http://databank.worldbank.org/data/

Uakhitzhanova, A., Shokhan, R. \& Omarova, A. et al. 2017. Entrepreneurial Environment in the Current Financial Politics of Kazakhstan. Journal of Advanced Research in Law and Economics, 4(26), pp. 1371-1374. https://doi.org/10.14505/jarle.v8.4(26).37

Vasylieva, N. 2018. Ukrainian Agricultural Contribution to the World Food Security: Economic Problems and Prospects. Montenegrin Journal of Economics, 14(4), pp. 215-224. https://doi.org/10.14254/1800-5845/2018.14-4.15

Velychko, O., Velychko, L. 2017. Management of inter-farm use of agricultural machinery based of the logistical system «BOA». Bulgarian Journal of Agricultural Science. 23(4), pp. 534-543. http://www.scopus.com/inward/record.url?eid=2-s2.0$\underline{85026907558 \& \text { partnerID=MN8TOARS }}$

Winkler, A.E. 1997. Economic decision-making by cohabitors: findings regarding income pooling, Applied Economics, 29(8), pp. 10791090. https://doi.org/10.1080/000368497326471

Xiao, J. 2015. The effects of acquisition on the growth of new technology-based firms: Do different types of acquirers matter? Small Business Economics, 45, pp. 487-504. https://doi.org/10.1007/s11187-015-9656-y 


\section{ENTREPRENEURSHIP AND SUSTAINABILITY ISSUES}

ISSN 2345-0282 (online) http://jssidoi.org/jesi/

2020 Volume 7 Number 4 (June)

http://doi.org/10.9770/jesi.2020.7.4(12)

Xue-Guo, Xu, Steven, Si, Joshua, Stout and John Zhengjie Feng 2012. An innovative approach of the mechanism of organizational synergetic learning in emerging economy. Problems and Perspectives in Management, 10(3), pp. 67-74.

https://businessperspectives.org/journals/problems-and-perspectives-in-management/issue-37/an-innovative-approach-of-the-mechanismof-organizational-synergetic-learning-in-emerging-economy

Zavadska, D. 2018. Determining the role of banks in the financing of innovative development processes of the economy. Baltic Journal of Economic Studies, 4(3), pp. 68-73. https://doi.org/10.30525/2256-0742/2018-4-3-68-73

Zhylinska, O., Stepanova, A., Horbas, I. 2017. Effective synergic interaction of strategic business units of diversified company. Problems and Perspectives in Management, 15(4), pp. 38-49. https://doi.org/10.21511/ppm.15(4).2017.04

Taipov, T. 2018. Public support models of agricultural production in the EAEU countries. Bulletin of the Karaganda University. Economy Series, 2(90), pp. 91 -98. http://rep.ksu.kz/handle/data/3869

\section{Svitlana KHALATUR}

ORCHID ID: https://orcid.org/0000-0001-8331-3341

\section{Svitlana KHAMINICH}

ORCHID ID: https://orcid.org/0000-0001-6894-6909

Oksana BUDKO

ORCHID ID: https://orcid.org/0000-0002-3354-6515

Olesia DUBOVYCH

ORCHID ID: https://orcid.org/0000-0003-3390-1393

Oleksandr KARAMUSHKA

ORCHID ID: https://orcid.org/0000-0002-9369-7972

Register for an ORCID ID:

https://orcid.org/register

Copyright (C) 2020 by author(s) and VsI Entrepreneurship and Sustainability Center

This work is licensed under the Creative Commons Attribution International License (CC BY).

http://creativecommons.org/licenses/by/4.0/

CC) (i) Open Access 